\title{
"Infection prevention and control idea challenge" contest: a fresh view on medical education and problem solving
}

\author{
Arash Arianpoor 1,2, Ahmadreza Zarifian 2,3,4, Emran Askari, ${ }^{2,5}$, Arash Akhavan-Rezayat ${ }^{2,4}$, Mojtaba Dayyani ${ }^{4,6}$, \\ Amin Rahimiann ${ }^{2,4}$, Elahe Amini ${ }^{1,4}$, Roya Amel ${ }^{2,4}$, Aghigh Ziaeemehr ${ }^{1}$, Walter Zingg ${ }^{7}$, \\ Mohammad Hasan Aelami ${ }^{8^{*}}$ and Didier Pittet ${ }^{7 *}$
}

\begin{abstract}
Background: Healthcare-associated infections (HAls) challenge modern medicine. Considering their high prevalence in Iran, we aimed to provide knowledge on the subject, and to teach about the importance of infection prevention and control (IPC) to a broad audience of pre-graduate healthcare professionals, focusing on education as the cornerstone of IPC.

Main body: We invited Iranian medical students to present ideas on "how to reduce HAls." Projects were eligible if being original and addressing the call. Accepted projects were quality assessed using a scoring system. Forty-nine projects were submitted, of which 37 met the inclusion criteria. They had a mean score of $69.4 \pm 18.3$ out of the maximum possible score of 115. Four reviewers assessed the 37 projects for clinical applicability, impact on patient safety, and innovation, and selected the best 12 to compete at the 2 nd International Congress on Prevention Strategies for Healthcare-associated Infections, Mashhad, Iran, 2018. The competition took place in three rounds. The selected teams presented their projects in the first round and debated one by one in a knockout manner, while the jury reviewed their scientific content and presentation skills. In the second round, the top 5 projects competed for reaching the final stage, in which the teams presented their ideas in front of a panel of international IPC experts to determine the first three ranks. At the end of the contest, the participants gained valuable criticisms on how to improve their ideas. Moreover, by its motivating atmosphere, the contest created an excellent opportunity to promote IPC in medical schools.
\end{abstract}

Conclusions: Using innovation contests in pre-graduates is an innovative education strategy. It sensitizes medical students to the challenges of IPC and antimicrobial resistance and drives them to think about solutions. By presenting and defending their innovations, they deepen their understanding on the topic and generate knowledge transfer in both ways, from students to teachers and vice versa.

Keywords: Infection control, Healthcare-associated infections, Medical education, Problem solving, Antimicrobial resistance, Surgical site infection, Hand hygiene, Healthcare economy

\section{Background}

Healthcare-associated infections (HAIs) and antimicrobial resistance are among the most serious challenges in modern medicine, affecting both patients and healthcare workers $(\mathrm{HCW})$. The global HAI prevalence has been

\footnotetext{
* Correspondence: AelamiMH@mums.ac.ir; didier.pittet@hcuge.ch

${ }^{8}$ Infection Control and Hand Hygiene Research Center, Imam Reza Hospital, Mashhad University of Medical Sciences, Shariati Square, Mashhad, Iran

Infection Control Programme and World Health Organization Collaborating Centre on Patient Safety, University of Geneva Hospitals and Faculty of Medicine, 4 Rue Gabrielle-Perret-Gentil, 1211 Geneva, Switzerland Full list of author information is available at the end of the article
}

reported to be up to $15.5 \%$ in low and middle income countries, and the number is growing [1-5]. On the other hand, 35 to $55 \%$ of HAIs can be reduced by applying multimodal infection control measures [6].

Many barriers affect best practice of infection prevention and control (IPC) measures, but the lack of knowledge on implementing IPC strategies and low compliance with best practice guidelines are among the most important. Various ideas to increase compliance toward IPC guidelines have been published, most of which include educational programmes taking into account local contexts [7]. A Chinese

(c) The Author(s). 2020 Open Access This article is distributed under the terms of the Creative Commons Attribution 4.0 International License (http://creativecommons.org/licenses/by/4.0/), which permits unrestricted use, distribution, and 
group reported their positive experience in implementing an educational intervention among nurses that significantly improved knowledge, practice, and behaviour related to universal precaution measures [8]. A one-day course on IPC practices regarding central venous catheter (CVC) insertion for medical students and physicians in the US resulted in a significant decrease of CVC-associated infections 18 months after the event [9]. Education both for underand postgraduates is key, and the World Health Organization (WHO) emphasized the importance of formal education in IPC in their guidelines [10].

Ex-cathedra education or training focusing on knowledge alone is not sufficient for behaviour change, and the implementation of IPC strategies is most effective when applying a multimodal strategy $[10,11]$. The multimodal approach of the Geneva hand hygiene model using system change (move from hand washing to hand rubbing), educational tools, reminders in the work environment, active participation of staff, surveillance and feedback, as well as credible involvement of leaders not only improved hand hygiene compliance but also reduced HAI and crosstransmission of multi-drug-resistant organisms [12]. Consistently, WHO developed and promoted a multimodal implementation strategy for hand hygiene improvement that are feasible, sustainable, and adaptable to different contexts. The strategy was reported to improve both knowledge of and compliance with hand hygiene in both different geographical regions and different healthcare settings $[13,14]$. Multimodal strategies were identified as one of the key components for effective IPC strategies in acute care [15], and also were identified as one of the WHO core components for IPC, both at institutional and national levels $[10-14,16,17]$.

Compliance with best practice procedures differs among healthcare professions, with doctors often be less compliant toward basic IPC measures such as hand-hygiene [18]. Thus, more effort should be invested in improving compliance of doctors with best practice procedures. An integrated IPC curriculum during medical school would help to achieve this goal. Although multimodal implementation strategies are the most effective way to improve IPC practices $[13,15,17]$, it is difficult to communicate this concept to medical students.

To overcome the challenge of sensitizing medical students to the burden of HAI in Iran [3, 4, 19], and delivering concepts of best practice in a complex multidisciplinary work context, to which students have not been fully exposed, the Mashhad Medical Microbiology Student Research Group [MMMSRG] organized workshops, campaigns, and conferences on IPC [2]. Here, we describe the "Infection Prevention and Control Idea Challenge" contest, which was organized as part of the " $2^{\text {nd }}$ International Congress on Prevention Strategies for Healthcare-Associated Infections" in April 2018 in Mashhad, Iran.

\section{The "Infection Prevention and Control Idea Challenge" contest}

The "Infection Prevention and Control Idea Challenge" was advertised and promoted by MMMSRG on January 2, 2018 , on the congress website and via social media. Medical students, who were known to MMMSRG, were directly addressed to act as ambassadors for the contest at their local medical school. This promotional activity by itself initiated a movement to organize IPC campaigns and workshops in different medical schools, to teach medical students the basics of IPC, and to motivate and prepare them to develop and submit projects to the contest.

A panel of IPC experts, journal editors, and reviewers designed formats for collecting ideas (Fig. 1), assessing their eligibility for oral presentation (Table 1) and evaluating the projects and their presentations by the participating students (Table 2). Projects had to be submitted using a pre-defined format (Fig. 1), addressing one of the four main areas of the contest:

1. Adherence to hand hygiene guidelines: "How can we remove the barriers (to appropriate adherence to hand hygiene guidelines)?"

2. Antibiotic stewardship: "How do we manage antibiotic misuse and overuse?"

3. Post-surgical and procedure-related infections: "What is the best solution (to prevent post-surgical and procedure-related infections)?"

4. The role of society and economy in IPC: "How can we advertise and get a return on investment in IPC?"

With 49 submitted projects, the resonance of the call was unexpectedly high. A single reviewer reviewed the projects to check formal eligibility. Twelve projects were excluded for plagiarism or not being submitted in the correct format. The 37 remaining projects were evaluated and scored by four reviewers (2 national and 2 international IPC experts) based on pre-determined evaluation criteria (Table 1).

The mean scores of the projects are summarised in Table 3. Of a maximum of 115 , the mean ( \pm standard deviation) score of the 37 accepted projects was 69.4 ( \pm 18.3), ranging from 21.0 to 92.3 (Table 3). Based on consensus among the organisers of the contest, the 12 projects with the highest scores were selected to be presented at the conference. Details of these projects are summarized in Table 4.

Three rounds of project presentations were organised during the conference to select three winners. The first round grouped the selected 12 teams (Table 4) into six pairs based on the proximity of their project ideas. Each team competed to the allocated other team. They were allowed to see the abstracts of their competitors before presentation for better criticism. Each project was discussed 


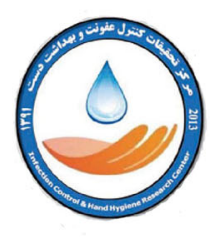

\section{Project Submission Form}
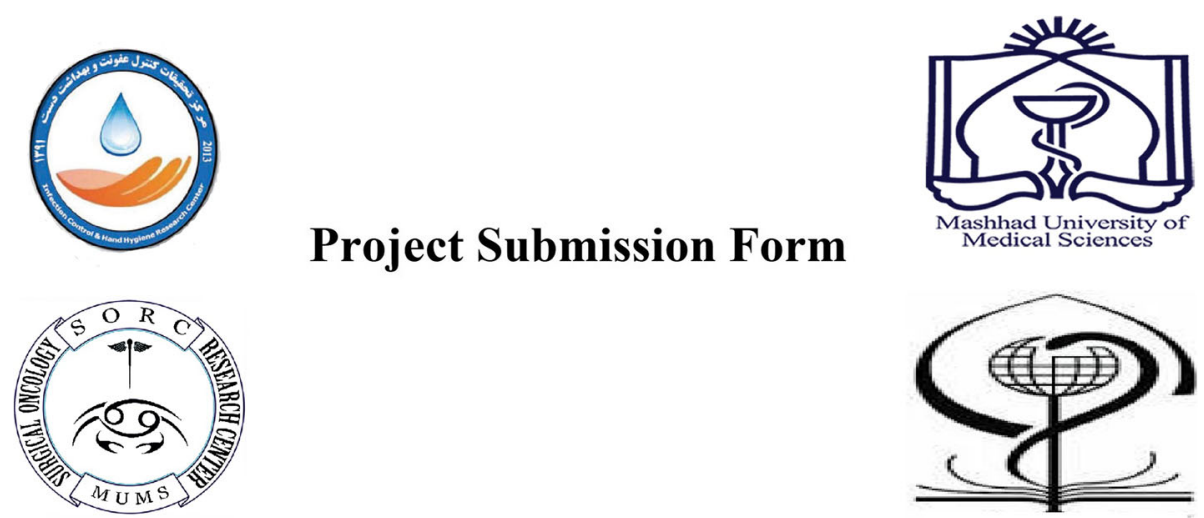

\section{Title of the project:}

\begin{tabular}{|l|l|l|l|l|}
\hline \multicolumn{4}{|l|}{ Authors' Details } \\
\hline Full Name & Phone & E-mail & $\begin{array}{l}\text { Field of } \\
\text { Study }\end{array}$ & Affiliation \\
\hline & & & & \\
\hline & & & & \\
\hline & & & & \\
\hline
\end{tabular}

1. Explain the main idea (200 words).

2. Suggest strategies for implementation of the idea (1000 words).

3. Identify the potential barriers to implementation of idea and suggest possible solutions.

4. Describe the anticipated outcomes of your project.

5. What are the requirements for implementing the idea?

6. List the references (maximum 15 references).

Fig. 1 Project submission form of the "Infection Prevention and Control Idea Challenge" contest

for $15 \mathrm{~min}$ : the team presented the main concepts of their project in the first $5 \mathrm{~min}$; the competitor team had the opportunity to express criticism in the second $5 \mathrm{~min}$; the presenting team had time to address questions and concerns raised by the competitors in the last $5 \mathrm{~min}$. Content and presentation were assessed by a jury of 5 general practitioners using a pre-defined evaluation form (Table 2). The general practitioners have worked and published in the field of IPC and infectious diseases, and they have worked in both public and private hospitals. Of a maximum of 188, the mean ( \pm standard deviation) score was $129.7( \pm 18.0)$, ranging from 105.4 to 161.2 (Table 3). Although it was planned to select one team from each pair for the second round, only the top five projects were selected because some presentations were poor and the knock-out strategy would have eliminated good projects. The teams of the five selected projects had to modify their project based on the comments raised by the jury members in preparation for the second round.

In the second round, the teams had $5 \mathrm{~min}$ to present their revised projects, which was followed by two minutes during which all other competitors could express criticism and concerns. The presenting team then had another $5 \mathrm{~min}$ to address criticism and raised concerns. The same jury from the first round also assessed the projects in the second round, using the same scoring form (Table 2). The top three projects were invited to be presented in the final round on the last day of the conference to a mixed national (1) and international (3) expert panel (Table 3). The experts ranked the projects using the pre-defined evaluation form (Table 2).

Table 4 summarises the 12 projects presented at the conference in descending order of the scores. The three winning projects are summarised below: 
Table 1 The primary evaluation rubric of the "Infection Prevention and Control Idea Challenge" contest

Title of the Idea

Main Question

Team Number

Presenter

\begin{tabular}{|c|c|c|c|c|c|c|}
\hline & & $\begin{array}{l}\text { Poor } \\
\text { (1) }\end{array}$ & $\begin{array}{l}\text { Fair } \\
(2)\end{array}$ & $\begin{array}{l}\text { Average } \\
\text { (3) }\end{array}$ & $\begin{array}{l}\text { Good } \\
\text { (4) }\end{array}$ & $\begin{array}{l}\text { Excellent } \\
\text { (5) }\end{array}$ \\
\hline \multicolumn{7}{|l|}{ Title } \\
\hline & $\begin{array}{l}\text { Well } \\
\text { Chosen/Question } \\
\text { Oriented? }\end{array}$ & & & & & \\
\hline & Good Structure? & & & & & \\
\hline & Innovative? & & & & & \\
\hline \multicolumn{7}{|c|}{ Background and Idea Explanation } \\
\hline & $\begin{array}{l}\text { Well written/Good } \\
\text { English Structure? }\end{array}$ & & & & & \\
\hline \multicolumn{2}{|c|}{$\begin{array}{l}\text { Suggested Strategies and } \\
\text { Executive Plan }\end{array}$} & $\begin{array}{l}\text { Poor } \\
\text { (11) }\end{array}$ & $\begin{array}{l}\text { Fair } \\
(12)\end{array}$ & $\begin{array}{l}\text { Average } \\
\text { (13) }\end{array}$ & $\begin{array}{l}\text { Good } \\
\text { (14) }\end{array}$ & $\begin{array}{l}\text { Excellent } \\
\text { (15) }\end{array}$ \\
\hline & Applicable? & & & & & \\
\hline & $\begin{array}{l}\text { Cost } \\
\text { effective/benefit? }\end{array}$ & & & & & \\
\hline & $\begin{array}{l}\text { Well Explained? } \\
\text { (Step by Step) }\end{array}$ & & & & & \\
\hline \multicolumn{7}{|c|}{$\begin{array}{l}\text { Does this proposition suggest an } \\
\text { innovative idea? }\end{array}$} \\
\hline \multicolumn{2}{|c|}{ Barriers and Risks } & $\begin{array}{l}\text { Poor } \\
(1)\end{array}$ & $\begin{array}{l}\text { Fair } \\
\text { (2) }\end{array}$ & $\begin{array}{l}\text { Average } \\
\text { (3) }\end{array}$ & $\begin{array}{l}\text { Good } \\
\text { (4) }\end{array}$ & $\begin{array}{l}\text { Excellent } \\
\text { (5) }\end{array}$ \\
\hline & $\begin{array}{l}\text { Well analyzed? } \\
\text { (from every } \\
\text { possible angles) }\end{array}$ & & & & & \\
\hline & $\begin{array}{l}\text { Suggests } \\
\text { Reasonable } \\
\text { /Applicable } \\
\text { Solutions? }\end{array}$ & & & & & \\
\hline \multicolumn{7}{|c|}{ Expected Impact and Outcome } \\
\hline & Reasonable? & & & & & \\
\hline & $\begin{array}{l}\text { The outcome } \\
\text { Solves a Major } \\
\text { problem? }\end{array}$ & & & & & \\
\hline \multicolumn{2}{|l|}{ References } & $\begin{array}{l}\text { Poor } \\
(1)\end{array}$ & $\begin{array}{l}\text { Fair } \\
\text { (2) }\end{array}$ & $\begin{array}{l}\text { Average } \\
\text { (3) }\end{array}$ & $\begin{array}{l}\text { Good } \\
\text { (4) }\end{array}$ & $\begin{array}{l}\text { Excellent } \\
\text { (5) }\end{array}$ \\
\hline & Well Selected? & & & & & \\
\hline & Up to date? & & & & & \\
\hline \multicolumn{7}{|l|}{ General } \\
\hline \multicolumn{7}{|c|}{ Total Score (out of 115) } \\
\hline Comments & & & & & & \\
\hline
\end{tabular}

Reviewer's Name and Affiliation:

1. The next generation of alcohol-based handrub containers: The main innovative idea was to design an alcohol-based handrub container connected to a counter. This counter would not only show the number of times the HCWs use it, but it would also display an inspirational scientific fact about the importance of hand-hygiene, HAIs, and IPC practices. The main concept behind this idea was that behaviour change toward hand hygiene needs not only education but also motivation.

2. An automatic hand-hygiene monitoring system: This project was based on "monitoring and surveillance" as an integral part of IPC. The innovative aspect of this idea was an electronic badge connected to the handrub dispenser, which grants entrance to patient rooms or triggers an alarm: 
Table 2 The final evaluation rubric of the "Infection Prevention and Control Idea Challenge" contest

\section{Infection Prevention \& Control Idea Challenge (Presentation Rubrics)}

Title of the Idea

Main Question

Team Number Presenter

\begin{tabular}{|c|c|c|c|c|}
\hline \multicolumn{5}{|c|}{ Presentation Skills \& Design } \\
\hline Non-verbal Skills & Poor (1) & Fair (2) & Average (3) & Good (4) \\
\hline Eye Contact & $\begin{array}{l}\text { No eye contact with the audience, as } \\
\text { entire report is read from notes. } \\
\text { O }\end{array}$ & $\begin{array}{l}\text { Displayed minimal eye contact } \\
\text { with audience, while reading } \\
\text { mostly from the notes. } \\
\end{array}$ & $\begin{array}{l}\text { Consistent use of direct eye } \\
\text { contact with audience, but still } \\
\text { returns to notes. } \\
\end{array}$ & $\begin{array}{l}\text { Holds attention of entire audience with } \\
\text { the use of direct eye contact, seldom } \\
\text { looking at note. } \\
\text {. }\end{array}$ \\
\hline Body Language & $\begin{array}{l}\text { No movement or descriptive gestures. } \\
\text { O }\end{array}$ & $\begin{array}{l}\text { Very little movement or } \\
\text { descriptive gestures. } \\
O\end{array}$ & $\begin{array}{l}\text { Made movements or gestures } \\
\text { that enhances articulation. } \\
\text { P }\end{array}$ & $\begin{array}{l}\text { Movements seem fluid and help the } \\
\text { audience visualize. }\end{array}$ \\
\hline Poise & $\begin{array}{l}\text { Tension and nervousness is obvious; } \\
\text { has trouble recovering from mistakes } \\
\text { S }\end{array}$ & $\begin{array}{l}\text { Displays mild tension; has } \\
\text { trouble recovering from } \\
\text { mistakes. } \\
\text {. }\end{array}$ & $\begin{array}{l}\text { Makes minor mistakes, but } \\
\text { quickly recovers from them; } \\
\text { displays little or no tension. } \\
\end{array}$ & $\begin{array}{l}\text { Student displays relaxed, self-confident } \\
\text { nature about self, with no mistakes. } \\
\text {. }\end{array}$ \\
\hline Verbal Skills & Poor (1) & Fair (2) & Average (3) & Good (4) \\
\hline Enthusiasm & $\begin{array}{l}\text { Shows absolutely no interest in topic } \\
\text { presented. }\end{array}$ & $\begin{array}{l}\text { Shows some negativity toward } \\
\text { topic presented. }\end{array}$ & $\begin{array}{l}\text { Occasionally shows positive } \\
\text { feelings about topic. } \\
\text {. }\end{array}$ & $\begin{array}{l}\text { Demonstrates a strong, positive feeling } \\
\text { about topic during entire presentation. } \\
\end{array}$ \\
\hline Elocution & $\begin{array}{l}\text { Student mumbles, incorrectly } \\
\text { pronounces terms, and speaks too } \\
\text { quietly for a majority of students to } \\
\text { hear. } \\
\\
\end{array}$ & $\begin{array}{l}\text { Student's voice is low. Student } \\
\text { incorrectly pronounces terms. } \\
\text { Audience members have } \\
\text { difficulty hearing presentation. } \\
0\end{array}$ & $\begin{array}{l}\text { Student's voice is clear. } \\
\text { Student pronounces most } \\
\text { words correctly. Most audience } \\
\text { members can hear } \\
\text { presentation. } \\
0\end{array}$ & $\begin{array}{l}\text { Student uses a clear voice and correct, } \\
\text { precise pronunciation of terms so that } \\
\text { all audience members can hear } \\
\text { presentation. } \\
\end{array}$ \\
\hline Visual Aids & Poor (1) & Fair (2) & Average (3) & Good (4) \\
\hline & Just Reading from notes & $\begin{array}{l}\text { A simple Power-point } \\
\text { Presentation } \\
0\end{array}$ & $\begin{array}{l}\text { A Power-point presentation } \\
\text { with appropriate graphics, } \\
\text { charts and tables } \\
\text { O }\end{array}$ & $\begin{array}{l}\text { Presentation is designed with other } \\
\text { software (Prezi, Keynote, SlideDog, etc.) } \\
\text { Use of other presentation tools (board, } \\
\text { printed charts, etc.) } \\
\end{array}$ \\
\hline
\end{tabular}

\begin{tabular}{|c|c|c|c|c|}
\hline \multicolumn{5}{|c|}{ Content \& Organization } \\
\hline Organization & Poor (1) & Fair (2) & Average (3) & Good (4) \\
\hline $\begin{array}{l}\text { Logical Sequence of information } \\
\text { presentation }\end{array}$ & 0 & 0 & 0 & 0 \\
\hline $\begin{array}{l}\text { Different sections are emphasized (i.e. } \\
\text { Background, Idca Prescntation, Suggcstcd } \\
\text { strategies, ...) }\end{array}$ & 0 & $\mathrm{O}$ & $\mathrm{O}$ & $\mathrm{O}$ \\
\hline $\begin{array}{l}\text { Presentation ends with a conclusion } \\
\text { section }\end{array}$ & 0 & 0 & 0 & 0 \\
\hline Presentation is referenced appropriately & 0 & 0 & 0 & 0 \\
\hline Good English Structure? & 0 & $\mathrm{O}$ & 0 & 0 \\
\hline Time Management & 0 & 0 & 0 & 0 \\
\hline Content & Poor (5) & Fair (10) & Average (15) & Good (20) \\
\hline Is the Idea Novel? (Worldwide or in Iran) & 0 & 0 & 0 & $\mathrm{O}$ \\
\hline $\begin{array}{l}\text { Idea is well described and backed with } \\
\text { concrete references? }\end{array}$ & 0 & 0 & 0 & 0 \\
\hline Suggested Strategies are applicable? & 0 & 0 & 0 & $\mathrm{O}$ \\
\hline Suggested Strategies are cost-effective? & 0 & 0 & 0 & 0 \\
\hline $\begin{array}{l}\text { Student Know the Barriers and suggest } \\
\text { reasonable solutions? }\end{array}$ & 0 & 0 & 0 & 0 \\
\hline $\begin{array}{l}\text { Are Reference valid, well-selected and Up } \\
\text { to Date? }\end{array}$ & 0 & $\mathrm{O}$ & 0 & 0 \\
\hline \multicolumn{5}{|l|}{ Comments } \\
\hline General Opinion & $\begin{array}{l}\text { Poor (5) } \\
0\end{array}$ & $\mathrm{O}^{\text {Fair }(10)}$ & $\mathrm{O}^{\text {Average }\{15\}}$ & $\begin{array}{l}\text { Good (20) } \\
\mathrm{O}\end{array}$ \\
\hline \multicolumn{5}{|l|}{ Total Score (out of 188) } \\
\hline Reviewer's Name: & & & & \\
\hline
\end{tabular}


Table 3 Titles and attributed scores of the received ideas

\begin{tabular}{|c|c|c|c|c|c|}
\hline No & Title of the Project & $\begin{array}{l}\text { Mean score of the } \\
\text { primary review (out } \\
\text { of 115) }\end{array}$ & $\begin{array}{l}\text { Mean score of the } \\
1 \text { st round (out of } \\
\text { 188) }\end{array}$ & $\begin{array}{l}\text { Mean score of the } \\
\text { 2nd round (out of } \\
\text { 188) }\end{array}$ & $\begin{array}{l}\text { Mean score } \pm S D \text { of } \\
\text { the final presentation }\end{array}$ \\
\hline 1 & $\begin{array}{l}\text { The next generation of antiseptics (revised: The } \\
\text { next generation of antiseptic Containers) }\end{array}$ & $89.5 \pm 10.60$ & $151.2 \pm 2.28$ & $155 \pm 5.78$ & $160.5 \pm 19.84$ \\
\hline 2 & An automatic hand hygiene monitoring system & $87 \pm 24.04$ & $161.2 \pm 6.41$ & $163.2 \pm 6.37$ & $153 \pm 12.02$ \\
\hline 3 & Using the pocket chart to reduce antibiotic resistance & $88 \pm 15.55$ & $146.6 \pm 5.98$ & $153 \pm 6.59$ & $142.5 \pm 22.48$ \\
\hline 4 & $\begin{array}{l}\text { Post-operation patient care to prevent and control } \\
\text { infections through the use of a mobile application }\end{array}$ & $92.25 \pm 7.42$ & $141.8 \pm 5.49$ & $135.6 \pm 4.61$ & N/A \\
\hline 5 & Mobile handrub dispenser & $88 \pm 18.38$ & $137.2 \pm 5.71$ & $140.2 \pm 5.06$ & N/A \\
\hline 6 & $\begin{array}{l}\text { Developing an integrated antibiotic monitoring and } \\
\text { management governmental system to reduce resistance } \\
\text { to antibiotics }\end{array}$ & $90.5 \pm 14.84$ & $130.6 \pm 4.56$ & N/A & N/A \\
\hline 7 & $\begin{array}{l}\text { Prevention of implant-associated infections by using } \\
\text { electrospun nanofibers }\end{array}$ & $85 \pm 2.82$ & $122 \pm 6.63$ & N/A & N/A \\
\hline 8 & $\begin{array}{l}\text { Produce and use of new yarn stitches based on silver } \\
\text { nanoparticles }\end{array}$ & $84.5 \pm 17.67$ & $122.2 \pm 4.49$ & N/A & N/A \\
\hline 9 & $\begin{array}{l}\text { Nanotechnology: the open way of infection control, } \\
\text { prospects }\end{array}$ & $84.5 \pm 13.43$ & $115.2 \pm 5.06$ & N/A & N/A \\
\hline 10 & Bacteriotherapy for wound healing & $82.5 \pm 10.60$ & $117.6 \pm 3.04$ & $\mathrm{~N} / \mathrm{A}$ & N/A \\
\hline 11 & $\begin{array}{l}\text { How can we manage healthcare-associated infections } \\
\text { in hospitals? }\end{array}$ & $82.5 \pm 20.50$ & $105.8 \pm 6.41$ & N/A & N/A \\
\hline 12 & $\begin{array}{l}\text { Combination strategy (restriction-education) for antibiotic } \\
\text { stewardship program }\end{array}$ & $79.5 \pm 9.01$ & $105.4 \pm 7.02$ & N/A & N/A \\
\hline 13 & $\begin{array}{l}\text { Appropriate education of hand hygiene for children in } \\
\text { schools }\end{array}$ & $79 \pm 21.21$ & N/A & N/A & N/A \\
\hline 14 & $\begin{array}{l}\text { Prevention and control of vaginal infections associated } \\
\text { with swimming pools }\end{array}$ & $78 \pm 5.65$ & N/A & N/A & N/A \\
\hline 15 & $\begin{array}{l}\text { Establishing permanent workshops on skills and ideas } \\
\text { about prevention and control of infection in high schools }\end{array}$ & $77.5 \pm 0.70$ & N/A & N/A & N/A \\
\hline 16 & Ways to decrease the surgical site infection rate in Iran & $75.5 \pm 9.19$ & N/A & N/A & N/A \\
\hline 17 & $\begin{array}{l}\text { Side effects after surgery and recovery (make some } \\
\text { proprietary suture) }\end{array}$ & $75.5 \pm 20.50$ & N/A & N/A & N/A \\
\hline 18 & $\begin{array}{l}\text { Training ways to control and prevent oral infections } \\
\text { in elementary students }\end{array}$ & $75 \pm 12.72$ & N/A & N/A & N/A \\
\hline 19 & Antimicrobial resistance, as big a risk as terrorism & $75 \pm 12.72$ & N/A & N/A & N/A \\
\hline 20 & $\begin{array}{l}\text { Strategies for improving hand hygiene, as a preventive } \\
\text { measure against hospital-acquired infections }\end{array}$ & $75 \pm 16.97$ & N/A & N/A & N/A \\
\hline 21 & $\begin{array}{l}\text { Students as WHO health representatives in Iranian } \\
\text { schools; to modify previous strategies for better ones }\end{array}$ & $73.5 \pm 3.53$ & N/A & N/A & N/A \\
\hline 22 & $\begin{array}{l}\text { Early diagnosis of prosthetic joint infections: focus on } \\
\text { biomarkers }\end{array}$ & $70.5 \pm 10.60$ & N/A & N/A & N/A \\
\hline 23 & $\begin{array}{l}\text { Prevention of infection by diagnosing cancer through } \\
\text { biomarker levels and dielectric qualities as a minimally } \\
\text { invasive and novel method }\end{array}$ & $68.5 \pm 7.77$ & N/A & N/A & N/A \\
\hline 24 & $\begin{array}{l}\text { Placebo prescription and home remedies; a novel but } \\
\text { ignored method in Iran }\end{array}$ & $68 \pm 7.07$ & N/A & N/A & N/A \\
\hline 25 & Online medical network and acute infections control & $67.5 \pm 7.77$ & N/A & N/A & N/A \\
\hline 26 & A traditional solution for antibiotic overuse & $67.25 \pm 18.03$ & N/A & N/A & N/A \\
\hline 27 & Monitoring policy for antibiotics therapy & $65 \pm 0$ & N/A & N/A & N/A \\
\hline 28 & Adherence to hand hygiene guidelines & $60.5 \pm 2.12$ & N/A & N/A & N/A \\
\hline 29 & Fixing policies and education & $56.5 \pm 31.81$ & N/A & $\mathrm{N} / \mathrm{A}$ & N/A \\
\hline 30 & Our hands, where all things begin & $55.5 \pm 7.77$ & N/A & $\mathrm{N} / \mathrm{A}$ & N/A \\
\hline
\end{tabular}


Table 3 Titles and attributed scores of the received ideas (Continued)

\begin{tabular}{|c|c|c|c|c|c|}
\hline No & Title of the Project & $\begin{array}{l}\text { Mean score of the } \\
\text { primary review (out } \\
\text { of } 115 \text { ) }\end{array}$ & $\begin{array}{l}\text { Mean score of the } \\
\text { 1st round (out of } \\
188 \text { ) }\end{array}$ & $\begin{array}{l}\text { Mean score of the } \\
\text { 2nd round (out of } \\
\text { 188) }\end{array}$ & $\begin{array}{l}\text { Mean score } \pm \text { SD of } \\
\text { the final presentation }\end{array}$ \\
\hline 31 & $\begin{array}{l}\text { Antibiotic stewardship: How do we manage antibiotic } \\
\text { misuse and overuse? }\end{array}$ & $55.25 \pm 15.20$ & N/A & N/A & N/A \\
\hline 32 & Surgery without infection & $48.5 \pm 13.61$ & N/A & N/A & N/A \\
\hline 33 & Controlling respiratory infections in garrison & $46 \pm 14.31$ & N/A & N/A & N/A \\
\hline 34 & $\begin{array}{l}\text { Increasing the level of applied scientific information } \\
\text { of patients }\end{array}$ & $40 \pm 34.11$ & N/A & N/A & N/A \\
\hline 35 & Penicillin vs natural herbs esp. turnip & $35.25 \pm 33.58$ & N/A & N/A & N/A \\
\hline 36 & $\begin{array}{l}\text { Comparison of the effects and side effects of amoxicillin } \\
\text { and penicillin on teeth }\end{array}$ & $24.25 \pm 32.88$ & N/A & N/A & N/A \\
\hline 37 & Medical universities as an economic corporation & $21 \pm 23.51$ & N/A & N/A & N/A \\
\hline
\end{tabular}

a. The dispenser connected to the patient room works as a door key, so the door will open only if the HCW uses the handrub dispenser.

b. An infection control area is defined around the patient (patient zone); if a HCW enters this zone without using the handrub dispenser, an alarm (beeping sound, flashing light, or vibration) issued by the personal badge notifies the $\mathrm{HCW}$ to perform hand hygiene before approaching the patient.

c. The data collected by the badge will be used to monitor individual hand-hygiene compliance and may feed a reward-punishment system.

3. Using a pocket chart to reduce antibiotic resistance: This project focused on antibiotic stewardship. The main idea was to design a user-friendly chart called "Pocket Chart," which displays indications for starting and stopping antibiotics combined with a detailed report on local antibiotic resistance patterns. Although the main idea of using guidelines for an antibiotic prescription is not novel, guidelines taking into account local antimicrobial resistance are lacking in Iran. The team suggested that their "Pocket Chart" would be customized not only for each hospital but also for outpatient care.

\section{Outcome and impacts}

Although HAIs are a significant challenge for healthcare systems, it is believed that more than $30 \%$ of HAIs could be prevented by correct IPC measures [6, 20]. Unfortunately, adherence to best practices and guidelines is very low [10,21]. Even in an environment with numerous promotional campaigns on hand hygiene, compliance depends more on "peer pressure and the perception of high selfefficacy" than on reasoning [22]. Given that medical doctors repeatedly have been reported with low compliance to IPC measures such as hand-hygiene, it seems essential to integrate IPC in the curriculum of medical schools. However, as communicating multimodal behaviour change strategies to medical students might be challenging, an IPC contest can motivate students to engage in IPC and to invent innovative solutions. This adds to the main goal of medical education to have knowledgeable, skilled and up-to-date healthcare professionals who choose patients' interests over their own [23]. However, patient safety, and particularly IPC is a long-term investment and maintaining professional expertise needs continuous learning also after graduation [24].

Overall, our IPC idea challenge contest had four main outcomes:

1. Sensitizing medical students for the problems around IPC and antimicrobial resistance

2. Integrating IPC and antimicrobial resistance in the medical curricula

3. Fostering the creation of workshops and educational sessions on IPC and antimicrobial resistance

4. Encouraging medical students to be solution- rather than problem-oriented when thinking about challenges in IPC and antimicrobial resistance

By inviting the students to participate in this programme, we challenged them to get interested in IPC but also to think critically in terms of basic concepts, strategies, interventions, and implementation strategies. The high number of submitted projects of good quality combined with high motivation and investment by the medical students was a success, and thus, contests may be an effective educational strategy.

We reviewed all projects and provided feedback to all participants to help them to improve their ideas and make them more practical and implementable. The contest promoted education in both ways: from students to peers and experts, and from experts to students. The contest also provided an interactive environment via debates, in which participants learned to review projects and articulate concerns and constructive criticism. 
Table 4 Details of the 12 selected ideas presented orally

\begin{tabular}{|c|c|c|}
\hline Rank & Title & Main Idea \\
\hline 1 & $\begin{array}{l}\text { The next generation of antiseptics (revised: } \\
\text { The next generation of antiseptic Containers) }\end{array}$ & $\begin{array}{l}\text { The main innovative idea of this team was to design an alcohol-based handrub container } \\
\text { connected to a counter. This counter would not only show the number of times it is used } \\
\text { by the HCWs, but it would also show an inspirational scientific fact about the importance } \\
\text { of handrubs in hand-hygiene, hospital-acquired infections, and IPC practices. The main } \\
\text { concept behind this idea was that increasing hand-hygiene adherence needs motivation } \\
\text { and education. }\end{array}$ \\
\hline
\end{tabular}

2 An automatic hand hygiene monitoring system

This project was based on "monitoring and surveillance" as an integral part of IPC. The innovative aspect of this idea was designing an electronic badge for HCWs that is connected to the handrub dispenser and they suggested an integrated plan consisted of three parts:

1. All entrance doors should be connected to a handrub dispenser that will work as a key to the door, so the doors will open only if the handrub dispenser is used by the HCWs. Besides, the use of handrubs will be recorded by the electronic badge as a monitoring device.

2. An infection control area will be defined around patients' beds and if HCWs enter this area without using the handrub dispenser, an alarming signal (beeping sound, alarming light, or a vibration) via their badge will notify them to wash their hands before approaching to the patient.

3. The data collected by the badges will be used to monitor the hand-hygiene adherence among HCWs and may be used as a reward-punishment system to enforce this behaviour.

3 Using the pocket chart to reduce antibiotic resistance

5

Developing an integrated antibiotic monitoring and management governmental system to reduce resistance to antibiotics

Prevention of implant-associated infections by using electrospun nanofibers

Production and use of new yarn stitches based on silver nanoparticles

9 Nanotechnology: the open way of infection control, prospects

10 Bacteriotherapy for wound healing
This project was focused on antibiotic stewardship. The main idea was to design a user-friendly chart, called "Pocket Chart", including indications for starting antibiotics and antibiotic duration as well as a detailed report on antibiotic resistance patterns. Although the main idea of using guidelines for antibiotic prescription is not novel, local guidelines for different conditions are lacking in Iran. The team suggested that their Pocket Chart would be customized not only for each different hospital ward but also for different areas of the city for outpatients.

The main idea of this project was to design an app to monitor patients after surgery and develop a platform for easy communication between patients and doctors. The app would have 4 parts, i.e. patient's profile, notification panel, messaging, and question and answer part. The app would be supported by an online server containing medical records of the patients. The application would also make possible for different patients to communicate with each other and share their experiences. The application would gather information on patients' condition after surgery and notify their doctors in case any red flag signs occur.

This project focused on increasing the accessibility of the alcohol-based handrub solutions by designing a wearable handrub dispenser. The design included a wearable dispenser designed as a bracelet or armlet with a refillable container and a handrub container mounted on the walls that could be used to refill the bracelet/armlet.

This idea suggested an integrated monitoring and management system that oversees the antibiotic prescription and usage. This system includes three parts:

1. Developing a two-part visit strategy for doctors, in which all patients with an indication for antibiotic use will be prescribed with the appropriate antibiotic. After a few days, the patient's condition and response to antibiotic therapy will be evaluated

2. Developing an electronic system to record the amount of antibiotics prescribed for each patient and monitor their antibiotic use

3. Making strict rules for selling over-the-counter antibiotics Although these strategies are common in many developed healthcare system, in Iran we do not have an integrated system for antibiotic prescription monitoring

In this project, the contestants aimed to develop a polymeric dressing with tunable drug release to be used in orthopaedic surgeries. The designed dressing would be made through electrospinning process and contain desired antibiotics. They suggested that their dressing would be applied on the implant site before closing the wound in the operation room.

This team designed suture threads coated with silver nanoparticles to prevent surgical site infection.

This team designed a urinary catheter coated with silver nanoparticles to prevent urinary tract infections.

This project was mainly focused on a wound dressing that contains Lactobacillus rhamnosus GG and Lactobacillus plantarum isolates and prevents infections related 
Table 4 Details of the 12 selected ideas presented orally (Continued)

\begin{tabular}{lll}
\hline Rank Title & Main Idea \\
\hline $11 \quad$ How can we manage healthcare-associated & to diabetic foot. \\
infections in hospitals? & $\begin{array}{l}\text { Designing an electronic device containing patients' files and charts to replace } \\
\text { conventional charts was the focus. The device would scan HCWs' hands and } \\
\text { give access only to those with low bacterial contamination. }\end{array}$ \\
$12 \quad \begin{array}{l}\text { Combination strategy (restriction-education) } \\
\text { for antibiotic stewardship program }\end{array}$ & $\begin{array}{l}\text { This team developed an executive plan for antibiotic stewardship in three steps: } \\
\text { A. developing an electronic medical record software for monitoring antibiotic }\end{array}$ \\
& $\begin{array}{l}\text { use, B. imposing strict rules with severe fines for over-the-counter antibiotic } \\
\text { selling and C. mass education programs for general population. }\end{array}$
\end{tabular}

Another important outcome of our contest was linking students to their supervisors for identifying innovative ideas in IPC and to prepare a competitive project. The contest helped medical students to do both learn about a problem and come up with solutions. The opportunity to compete with peers from other universities in Iran, and attending an international conference probably were important incentives and drivers for investing in the contest.

\section{Conclusions}

Using innovation contests in pre-graduates is an innovative education strategy. It sensitizes medical students to the challenges of IPC and antimicrobial resistance and drives them to think about solutions. By presenting and defending their innovations, they deepen their understanding on the topic and generate knowledge transfer in both ways, from students to teachers and vice versa.

\section{Abbreviations}

AMR: Antimicrobial resistance; CVC: Central venous catheter; HAl: Healthcareassociated infections; HCW: Healthcare workers; IPC: Infection prevention and control; MMMSRG: Mashhad Medical Microbiology Student Research Group; WHO: The World Health Organization

\section{Acknowledgements}

We want to acknowledge Prof. John Conly, Dr. Amin Bojdi, Dr. Freshteh Sheibani, Prof. Ling Moi Lin, Prof. Petra Gastmeier, Dr. Mehdi Asadi and Mrs. Nasrin Khosravi Zenyani for their participation and support. We also would like to thank the executive team for their invaluable support to hold this contest.

\section{Authors' contributions}

AAr: Contest design and management; writing and revision of the manuscript. AZa: Data acquisition; writing and revision of the manuscript. EAs: Substantial contributions to contest and study design. AAR: Data acquisition and analysis. MD: Data acquisition and analysis. AR: Data acquisition and analysis. EA: Major contribution in writing the manuscript. RA: Major contribution in writing the manuscript. AZi: Major contribution in writing the manuscript. WZ: Projects' revision and revision of the manuscript. MHA: Contest design and supervision. DP: Critical revision and supervision of the study. All authors read and approved the final manuscript.

\section{Funding}

The "Infection Prevention and Control Idea Challenge" contest was planned and funded by the 2nd International Congress on Prevention Strategies for Healthcare-Associated Infections. This work was supported by the Infection Control Programme and WHO Collaborating Centre on Patient Safety (SPCl/ W(C), University of Geneva Hospitals and Faculty of Medicine, Geneva, Switzerland; hand hygiene research activities at the SPCI/WCC are also supported by the Swiss National Science Foundation (grant no. 32003B_163262).

\section{Availability of data and materials}

The datasets used and/or analysed during the current study are available from the corresponding author on reasonable request.

\section{Ethics approval and consent to participate}

Not applicable.

\section{Consent for publication}

Not applicable.

\section{Competing interests}

The authors declare that they have no competing interests.

\section{Author details}

${ }^{1}$ Surgical Oncology Research Center, Mashhad University of Medical Sciences, Mashhad, Iran. ${ }^{2}$ Mashhad Medical Microbiology Student Research Group, Mashhad University of Medical Sciences, Mashhad, Iran. ${ }^{3}$ Orthopaedic Research Center, Mashhad University of Medical Sciences, Mashhad, Iran. ${ }^{4}$ Student Research Committee, Mashhad University of Medical Sciences, Mashhad, Iran. ${ }^{5}$ Nuclear Medicine Resident, Mashhad University of Medical Sciences, Mashhad, Iran. ${ }^{6}$ Department of Neurology, McGovern Medical School, University of Texas Health Science Center at Houston, Houston, TX, USA. ${ }^{7}$ Infection Control Programme and World Health Organization Collaborating Centre on Patient Safety, University of Geneva Hospitals and Faculty of Medicine, 4 Rue Gabrielle-Perret-Gentil, 1211 Geneva, Switzerland. ${ }^{8}$ Infection Control and Hand Hygiene Research Center, Imam Reza Hospital, Mashhad University of Medical Sciences, Shariati Square, Mashhad, Iran.

Received: 3 September 2019 Accepted: 27 January 2020

Published online: 07 February 2020

\section{References}

1. Allegranzi B, Nejad SB, Combescure C, Graafmans W, Attar H, Donaldson L, et al. Burden of endemic health-care-associated infection in developing countries: systematic review and meta-analysis. Lancet. 2011;377:228-41.

2. Arianpoor A, Estaji F, Naderinasab M, Askari E. Antimicrobial susceptibility pattern of Staphylococcus aureus isolates against newly marketed antibiotics: a report from imam Reza Hospital of Mashhad, Iran. Razavi Int J Med. 2015;3:e31568

3. Eshrati B, Asl HM, Afhami S, Pezeshki Z, Seifi A. Health care-associated infections in Iran: a national update for the year 2015. Am J Infect Control. 2018;46:663-7.

4. Ghashghaee A, Behzadifar M, Azari S, Farhadi Z, Bragazzi NL, Behzadifar M, et al. Prevalence of nosocomial infections in Iran: a systematic review and meta-analysis. Med J Islam Repub Iran. 2018;32:48.

5. Heidary M, Nasiri MJ, Dabiri H, Tarashi S. Prevalence of drug-resistant Klebsiella pneumoniae in Iran: a review article. Iran J Public Health. 2018;47:317.

6. Schreiber PW, Sax H, Wolfensberger A, Clack L, Kuster SP. The preventable proportion of healthcare-associated infections 2005-2016: systematic review and meta-analysis. Infect Control Hosp Epidemiol. 2018;39:1277-95.

7. Gould D, Moralejo D, Drey N, Chudleigh J, Taljaard M. Interventions to improve hand hygiene compliance in patient care: reflections on three systematic reviews for the Cochrane collaboration 2007-2017. J Infect Prev. 2018;19:108-13.

8. Huang J, Jiang D, Wang X, Liu Y, Fennie K, Burgess J, et al. Changing knowledge, behavior, and practice related to universal precautions among hospital nurses in China. J Contin Educ Nurs. 2002;33:217-24. 
9. Sherertz RJ, Ely EW, Westbrook DM, Gledhill KS, Streed SA, Kiger B, et al, Education of physicians-in-training can decrease the risk for vascular catheter infection. Ann Intern Med. 2000;132:641-8.

10. Safety WHOP, World Health $\mathrm{O}$. WHO guidelines on hand hygiene in health care. 2009

11. Pittet D. Improving adherence to hand hygiene practice: a multidisciplinary approach. Emerg Infect Dis. 2001;7:234.

12. Pittet $D$, Hugonnet $S P$, Harbarth $S$, Mourouga $P$, Sauvan VR, Touveneau $S$, et al. Effectiveness of a hospital-wide programme to improve compliance with hand hygiene. Lancet. 2000;356:1307-12.

13. Allegranzi B, Gayet-Ageron AL, Damani N, Bengaly LN, McLaws M-L, Moro M-L, et al. Global implementation of WHO's multimodal strategy for improvement of hand hygiene: a quasi-experimental study. Lancet Infect Dis. 2013;13:843-51.

14. Pittet $D$, Allegranzi B, Storr J. The WHO clean care is safer care programme: field-testing to enhance sustainability and spread of hand hygiene improvements. J Infect Public Health. 2008;1:4-10.

15. Zingg W, Holmes A, Dettenkofer M, Goetting T, Secci F, Clack L, et al. Hospital organisation, management, and structure for prevention of healthcare-associated infection: a systematic review and expert consensus. Lancet Infect Dis. 2015;15:212-24.

16. Eggimann P, Harbarth S, Constantin M-NI, Touveneau S, Chevrolet J-C, Pittet D. Impact of a prevention strategy targeted at vascular-access care on incidence of infections acquired in intensive care. Lancet. 2000;355:1864-8.

17. Storr J, Twyman A, Zingg W, Damani N, Kilpatrick C, Reilly J, et al. Core components for effective infection prevention and control programmes: new WHO evidence-based recommendations. Antimicrob Resist Infect Control. 2017;6:6.

18. Humphreys H, Richards J. Undergraduate and postgraduate medical education on the prevention and control of healthcare-associated infection. More progress is needed. Int J Infect Control. 2011;7:12.

19. Esfandiari A, Salari H, Rashidian A, Asl HM, Foroushani AR, Sari AA. Eliminating healthcare-associated infections in Iran: a qualitative study to explore stakeholders' views. Int J Health Policy Manag. 2018;7:27-34.

20. Umscheid CA, Mitchell MD, Doshi JA, Agarwal R, Williams K, Brennan PJ. Estimating the proportion of healthcare-associated infections that are reasonably preventable and the related mortality and costs. Infect Control Hosp Epidemiol. 2011;32:101-14.

21. Sakamoto F, Asano K, Sakihama T, Saint S, Greene MT, Patel P, et al. Changes in health care-associated infection prevention practices in Japan: results from 2 national surveys. Am J Infect Control. 2019;47:65-8.

22. Sax H, Uçkay I, Richet H, Allegranzi B, Pittet D. Determinants of good adherence to hand hygiene among healthcare workers who have extensive exposure to hand hygiene campaigns. Infect Control Hosp Epidemiol. 2007;28:1267-74.

23. Swanwick T. Understanding Medical Education: Evidence, Theory and Practice. Hoboken: Wiley; 2011. p. 464.

24. Westerveld H, Briet J, Houwaart E, Legemaate J, Meerman TJ, Breetvelt E, et al. Dutch medical oath. Neth J Med. 2005;63:368-72.

\section{Publisher's Note}

Springer Nature remains neutral with regard to jurisdictional claims in published maps and institutional affiliations.

Ready to submit your research? Choose BMC and benefit from:

- fast, convenient online submission

- thorough peer review by experienced researchers in your field

- rapid publication on acceptance

- support for research data, including large and complex data types

- gold Open Access which fosters wider collaboration and increased citations

- maximum visibility for your research: over $100 \mathrm{M}$ website views per year

At BMC, research is always in progress.

Learn more biomedcentral.com/submissions 